\title{
Intensivmedisin i Norge
}

\author{
Norsk intensivmedisin har gjennomgått en betydelig utvikling siden starten i 1950-årene. \\ Fortsatt er faget sterkt integrert i anestesiologien, men utviklingen går mot enda større \\ bredde i behandlingen av kritisk syke. I 2006 ble over 10000 pasienter behandlet i løpet \\ av 50000 intensivdøgn ved norske intensivenheter. Utviklingen med en økende andel \\ eldre vil ytterligere øke presset på intensivsenger i Norge.
}

\section{Hans Flaatten}

hans.flaatten@helse-bergen.no Kirurgisk serviceklinikk

Haukeland universitetssykehus 5021 Bergen

\section{Eldar Søreide}

Anestesi- og intensivavdelingen

Divisjon for medisinsk service

Stavanger universitetssjukehus

Behandling av kritisk syke og skadede i egne enheter på sykehus har ingen lang tradisjon. De store polioepidemiene i Norden tidlig i 1950-årene utgjorde et vendepunkt internasjonalt for oppretting av egne intensivenheter. I Danmark gjorde den store pågangen av poliopasienter med akutt respirasjonssvikt at man ved Rigshospitalet i København innførte kontrollert overtrykksventilasjon og samling av slike pasienter på ett sted i sykehuset (1). Innsatsen førte til en halvering av dødeligheten, fra $87 \%$ til $40 \%$ i løpet av tre måneder. Den danske anestesiologen Bjørn Ibsen (1915-2007) var en sentral person i denne utviklingen (2). Dette er den historiske forklaringen på de tette båndene mellom anestesifaget og intensivmedisinen i Norden.

I 1990-årene startet en diskusjon internt i anestesimiljøet i Norden om intensivmedi- sinens plass innefor anestesiologien. Noen var tilhengere av en separasjon og hevdet at den tradisjonelle utdanningen av anestesiologer ikke lenger var tilstrekkelig for arbeidet på en intensivenhet. Diskusjonen gikk også innad i Nordisk anæsthesiologisk forening (nåværende Scandinavian Society of Anaesthesiology and Intensive Care, SSAI). Ikke bare forandret foreningen navn, men den la også grunnlaget for en satsing på en internordisk toårig videre spesialisering $\mathrm{i}$ intensivmedisin etter hvert i nært samarbeid med Den europeiske intensivforeningen (ESICM). Dette samarbeidet har nå vart i ti år, og over 200 leger har fullført en slik videreutdanning (3). I Norge førte debatten til at Legeforeningen utarbeidet en egen veileder i intensivmedisin i 1997 som ble revidert i 2001 (4).

I dag har alle akuttsykehus i Norge senger beregnet til voksne «intensivpasienter». Organiseringen varierer med sykehusets størrelse. Mens de større sykehusene har egne intensivenheter med øremerket personale og separat vaktordning for leger, har mindre sykehus gjerne slått intensivenheten sammen med annen akuttmedisinsk virksomhet, som for eksempel en medisinsk overvåkingsenhet og/eller postoperativ enhet, og dekkes av vakthavende lege fra anestesiavdelingen. Sengene blir fleksibelt utnyttet, og det er derfor ikke lett å angi det nøyaktige antall intensivsenger i Norge.

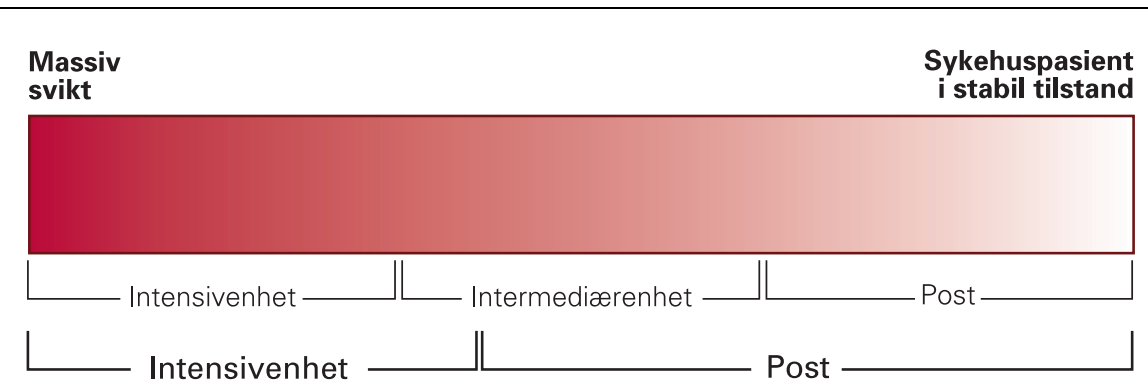

Figur 1 Forhold mellom grad av kritisk sykdom og nivå for behandling. Intermediærenheter vil kunne avlaste både intensivenheter og sengeavdelinger. Massiv svikt = svikt i vitale organfunksjoner
Det finnes ingen offisiell statistikk for virksomhet ved norske intensivenheter. Fra 1999 er slik informasjon samlet i Norsk Intensivregister (NIR) som nå mottar data fra 31 sykehus (www.intensivregister.no). Tall herfra indikerer at vi har rundt 270 generelle intensivsenger totalt $i$ Norge. I tillegg kommer noen senger på spesielle intensivseksjoner som ikke leverer data til NIR, trolig rundt 30 intensivsenger. De fleste norske intensivenhetene er små, med 5-10 sengeplasser. Norsk Intensivregister er i dag et nasjonalt kvalitetsregister som finansieres og eies av Helse Vest. Noen data fra registreringen for 2006 viser at dette ikke dreier seg om noen liten pasientgruppe, med 10979 pasientopphold som til sammen utgjorde 52316 intensivdøgn. Totalt 29130 respiratordøgn ble registrert $(55,6 \%$ av alle intensivdøgn).

I Norge er intensivenheter vanligvis organisert som en del av den anestesiologiske virksomheten. Ved noen av våre store sykehus finnes flere enheter, etter modell fra store sykehus i Europa. Her organiseres ofte virksomheten etter «organer» slik som hjerte- og nevrointensivenhet eller etter definerte pasientgrupper slik som pediatrisk og brannskadeintensivenhet etc. Pasienttilgangen er hovedproblemet med en slik sektororganisering med store svingninger i belegget. Det blir ikke flere kritisk syke om man splitter opp driften (5), og slik sett vil de fleste sykehus i Norge ha et pasientgrunnlag som blir for lite til en rasjonell drift av flere «sektorintensivenheter». Dette ble godt illustrert ved det nye St. Olavs hospital der en ny barneintensivenhet ikke ble åpnet som planlagt $i$ forbindelse med åpning av mor-barn-senteret.

\section{Bemanning}

Intensivsykepleierne har en toårig spesialutdanning og utgjør kjernen i bemanningen sammen med intensivlegene. Utviklingen har gått mot stadig mer avansert behandling og gir intensivsykepleierne et stort selvstendig faglig ansvar. Samtidig har behovet 


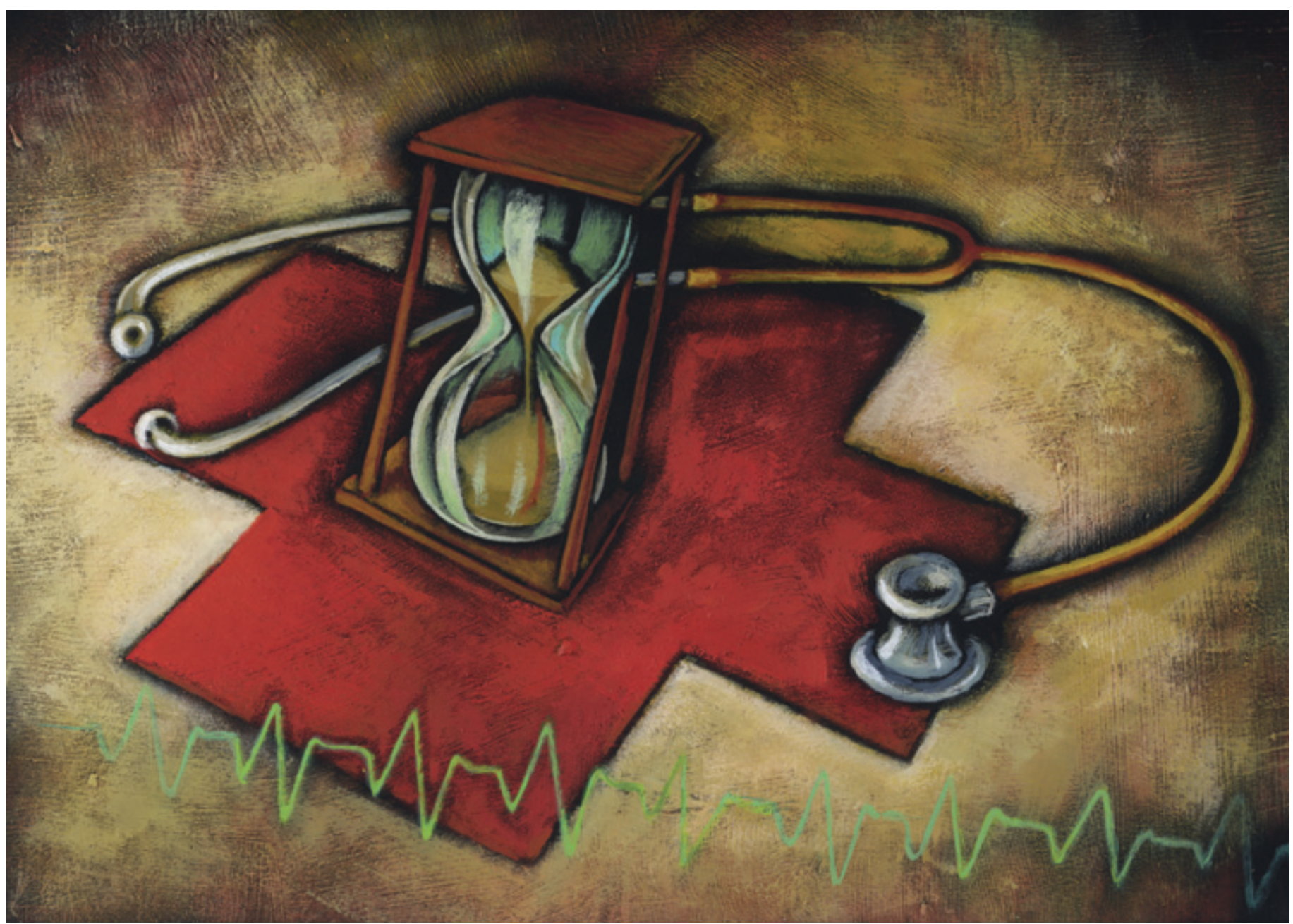

Illustrasjon Stein Løken

for informasjon og omsorg for pårørende øt betydelig. Forholdet mellom intensivsykepleiere og -pasienter har lenge vært satt til $1: 1$, men på grunn av den store kompleksiteten og arbeidsmengden har denne nå mange steder økt til 1,5 sykepleier per pasient. På legesiden ivaretar anestesiologer den daglige driften i nært samarbid med leger fra de respektive «moderavdelinger». Deres primære oppgave er å forestå behandlingen av vital organsvikt samt å koordinere den totale intensivmedisinske innsatsen fra det tverrfaglige team av leger, sykepleiere, fysioterapeuter og andre. Ved mindre sykehus jobber anestesiologene både med intensivmedisin og anestesivirksomhet, spesielt på vakttid. De fleste større sykehus har egne anestesiologer som kun arbeider med intensivmedisin. Innføring av den skandinaviske toårige intensivutdanningen gjør at de fleste større intensivenheter i dag har mange leger med slik tilleggskompetanse. Intensivmedisin er likevel en utpreget tverrfaglig aktivitet med betydelig involvering av leger fra alle de ulike kirurgiske og medisinske spesialitetene.

Behovet for intensivmedisinske kunnskaper også hos ikke-anestesiologer er økende. Av den grunn har man i intensivutdanningen til Scandinavian Society of Anaesthesiology and Intensive Care fra 2007 som et forsøk åpnet for at andre relevante spesialister kan delta, gitt at de har minst ett års erfaring fra en anestesiavdeling. Utviklingen går derfor også hos oss mot mer tverrfaglighet i legegruppen på de større intensivenhetene.

\section{Behov for intensivmedisinske ressurser}

Dekker dagens intensivmedisinske ressurser de reelle behovene i Norge? Dette finnes det ikke noe entydig svar på, men sammenliknet med tall fra USA synes vi å ha et lavt antall intensivsenger ved norske sykehus (6). Et problem hos oss er en skjevfordeling med relativt sett færre senger til intensivmedisin ved store spesialiserte sykehus, målt som antall intensivsenger/ antall totalt somatiske senger. Dette bildet må nyanseres ved at de store sykehusene kan sende ferdig behandlede pasienter tilbake til lokalsykehus for fortsatt intensivbehandling når det ikke er behov for kompetansen ved regionsykehuset, og vanligvis har flere såkalte intermediære enheter (stepdown units). Dette er sengeposter med for- sterket grunnbemanning, og som personalog utstyrsmessig ligger mellom en intensivavdeling og en ordinær sengepost (fig 1). Utbygd vil dette redusere presset på, og behovet for, de «tyngre» intensivenhetene.

I andre land har det vært gjort forsøk på å estimere behovet for ressurser til intensivmedisin, og trolig er erfaringene fra Wales de mest relevante å trekke frem for oss (7). Der estimerte de i 2000 behovet for intensivsenger til 30/500 000 og behovet for intermediærenheter til 55/500 000, dette for å tilfredsstille $95 \%$ av sengebehovet til enhver tid. Brukes tallene fra Wales, kommer man frem til et nasjonalt behov for 282 intensivsenger og 517 intermediærsenger totalt, eller seks intensivsenger og 11 intermediærsenger per 100000 innbyggere. Estimatet bygger på at en intensivenhet dekker en befolkning på 500000 . Deles dette på flere intensivenheter, vil behovet for antall senger øke. Antall senger ved intermediærenheter i Norge er ukjent, mens antall intensivsenger er i størrelsesorden 300 , som samsvarer ganske bra med tall fra Wales, gitt at hver intensivenhet dekket en befolkning på ca. 500 000. Dette er langt fra tilfellet i Norge, og vårt samlede behov vil ligge over dette estimatet. Hvor 
mye over er ikke lett å vurdere, da dette også henger nøye sammen med vår sykehusstruktur.

Om behovet for intensivsenger i dag er vanskelig å beregne, blir det ikke mindre usikkert de neste 20 årene. Det finnes forhold som vil øke behovet for intensivressurser og forhold som kan dempe etterspørselen. Vi vet at antall eldre vil øke betydelig, og at eldre av ulike grunner i høyere grad enn yngre blir rapportert å ha større behov for intensivbehandling. Til tross for en økning i antall eldre i befolkningen de siste ti årene, har ikke andelen eldre ved intensivavdelingen, eksempelvis ved Haukeland universitetssykehus, økt (8). Det er heller ikke sikkert at de eldre ønsker omfattende intensivbehandling i livets sluttfase eller at det er ønskelig fra samfunnets side. De fleste mener at behovet for intensivsenger vil øke betydelig i takt med aldersutviklingen i befolkningen.

Den medisinske utviklingen går raskt, og vil også kunne påvirke behovet for intensivressurser i begge retninger. Pasienter som for ikke lenge siden ikke hadde noe medisinsk tilbud, eksempelvis innen kreftbehandling, tilbys i dag behandling. Dette øker igjen behovet for intensivressurser (jf. allogen beinmargstransplantasjon). I den andre ret- ningen trekker blant annet erfaringene med akutt intervensjonskardiologi. Andelen pasienter som dør etter akutt mykoardinfarkt, faller, og det gjør også behovet for intensivbehandling pga. kardiogent sjokk. Den allmenne samfunnsutviklingen i bl.a. transportsektoren, med bedre biler og tryggere veier har ført til reduksjon av antall skadede og døde i trafikken, noe som i sin tur har ført til et fall $i$ antall pasienter med alvorlige hodeskader i løpet av de siste ti årene (9).

En annen problemstilling er om vi vil ha $ø$ konomi og personale til å øke intensivmedisinsk behandling betydelig i vestlige land. Med den demografiske forskyvningen som ventes, følger også en betydelig reduksjon i den arbeidsføre del av befolkningen, noe som trolig vil ramme helsesektoren sterkt. Intensivenheter, med det store behovet for personale, vil i den situasjonen være spesielt sårbare.

Av disse grunner er det sterkt ønskelig med en bredt anlagt nasjonal utredning med tanke på organisering og dimensjonering av norsk intensivmedisin de kommende årene, noe lik den Bjørn Lind-utvalget gjorde for 20 år siden (10).

\section{Oppgitte interessekonflikter: Ingen}

\section{Litteratur}

1. Ibsen B. The anaesthetist's viewpoint on the treat ment of respiratory complications in poliomyelitis during the epidemic in Copenhagen, 1952. Proc R Soc Med 1954; 47: 72-4

2. Ricmond C. Obituaries: Bjørn Ibsen. BMJ 2007; 335: 674

3. Flaatten $\mathrm{H}$, Larsson A, Wernerman J. The intensivist training programme in the Scandinavian countries. Care of the Critically III 2004; 20: 76-8.

4. Den norske legeforening. Standard for intensivmedisin. www.legeforeningen.no/index.gan? id $=2678$ (1.4.2008).

5. Gisvold SE. Er det nye St. Olavs Hospital i ferd med å grunnstøte? Tidsskr Nor Lægeforen 2007; 127: 60

6. Halpern NA, Pastores SM, Thaler HT et al. Changes in critical care beds and occupancy in the United States 1985-2000: differences attributable to hospital size. Crit Care Med 2006; 34: 2105-12.

7. Lyons RA, Wareham K, Hutchings HA et al. Population requirement for adult critical-care beds: a prospective quantitative and qualitative study. Lancet 2000; 355: 595-8.

8. Flaatten $\mathrm{H}$. Intensive care in the very old: are we prepared? Acta Anaesthesiol Scand 2007; 51: 519-21.

9. Haugen 0. Kan hodeskadedødsfall forhindres? Tidsskr Nor Lægeforen 2005; 125: 1309.

10. Lind B, Aksnes E, Hovik A et al. Intensivavdelinger - råd om utforming linklusive behov og bemanningl. Trondheim: Norsk institutt for sykehusforskning, 1981

Manuskriptet ble mottatt 11.7. 2008 og godkjent 29.1. 2009. Medisinsk redaktør Are Brean. 